\title{
Nature, green economy and sustainable development: The outcomes of UN Rio+20 Conference on Sustainable Development
}

\author{
Marianne Kettunen ${ }^{1,2}$, Patrick ten Brink ${ }^{1}$ \\ I Institute for European Environmental Policy (IEEP) $\mathbf{2}$ clo Finnish Environment Institute (SYKE) \\ Corresponding author: Marianne Kettunen (MKettunen@ieep.eu)
}

Academic editor: Klaus Henle | Received 17 July 2012 | Accepted 2 August 2012 | Published 24 August 2012

Citation: Kettunen M, ten Brink P (2012) Nature, green economy and sustainable development: The outcomes of UN Rio+20 Conference on Sustainable Development. Nature Conservation 2: 1-6. doi: 10.3897/natureconservation.2.3704

\section{Keywords}

sustainable development, green economy, Rio+20, natural capital, ecosystem services

\section{Introduction}

The UN Conference on Sustainable Development (UNCSD / Rio+20) took place 20 22 June 2012, in Rio de Janeiro, Brazil. The conference was the third global high-level event on sustainable development, marking the 20th anniversary of the 1992 United Nations Conference on Environment and Development (UNCED) in Rio de Janeiro, and the 10th anniversary of the 2002 World Summit on Sustainable Development (WSSD) in Johannesburg.

The objective of the Rio +20 conference was to secure renewed global political commitment for sustainable development, assess the progress to date and identify remaining gaps in the implementation of existing commitments (e.g. Millennium Development Goals - MDGs - agreed in 2000) (UNCSD 2012a). In addition, the conference also aimed to address new and emerging global challenges for sustainable development. In this context, the conference focused on two themes: the role of a green economy 
in the context of sustainable development and poverty eradication, and improving the institutional framework for sustainable development. In addition, seven thematic areas in need of priority attention were highlighted including jobs, energy, sustainable cities, food security and sustainable agriculture, water, oceans and disaster readiness.

According to the organisers, Rio +20 brought together close to 30000 participants from across the world, making it the most attended conference in the history of the UN (UNCSD 2012a). This included representatives from over 190 UN Member States, including close to hundred Heads of State, Vice Presidents and Prime Ministers. In addition, close to 4000 representatives of media and over 10000 representatives of NGOs and other major groups were present.

\section{Key outcomes of the conference}

The key outcome of the Rio+20 conference was the adoption of a global political agreement by the Heads of State and Government and high level representatives to renew their commitments to sustainable development and poverty eradication, and to ensure the promotion of economically, socially and environmentally sustainable future for both current and future generations (UNCSD 2012b). The agreement (called "The Future We Want" declaration) also acknowledged that since 1992 there have been areas of insufficient progress and setbacks in the integration of the three dimensions of sustainable development (i.e. economic, environmental and social sustainability) into political agendas. These setbacks have been aggravated by multiple financial, economic, food and energy crises, which have threatened the ability of all countries, in particular developing countries, to achieve sustainable development. Consequently, it was seen crucial that countries would not backtrack from their commitments made in and since 1992.

One of the most awaited elements of the Rio+20 declaration was the agreement on green economy in the context of sustainable development and poverty eradication. A green economy is commonly defined as a low carbon, resource efficient and socially inclusive economy that aims to improve human well-being and social equity while significantly reducing environmental risks and ecological scarcities (UNEP 2011). After long negotiations (e.g. prior to Rio), countries finally agreed to consider green economy as one of the important tools available for achieving sustainable development and eradicating poverty. It was, however, stated that green economy policies would need to respect each country's national sovereignty over their natural resources taking into account national circumstances, objectives, and policy priorities. In other words, no agreement was reached regarding general global rules or roadmap(s) for green economy. These rather vague and national level driven commitments were a disappointment to many participants, including the EU, who would have welcomed more concrete and rigorous global commitments related to the transition to green economy (EU press 2012).

In terms of nature, maintaining the healthy functioning of the Earth's ecosystems (e.g. removing unsustainable patterns of production and consumption that undermine biodiversity conservation) is mentioned as one of the purposes for green economy. 
In addition, the direct dependency of people - especially the poor - on ecosystems and their services for livelihoods, economic, social and physical well-being, and cultural heritage is emphasised. Disappointingly, however, no specific reference is made to "greening" the existing monitoring and accounting systems for green economy, including the importance of integrating the (non-market) values of ecosystem services into national accounting frameworks. Also, no links are made to the multiple ways how working with nature (i.e. investing in so called natural capital) can proactively support the transition to green economy (ten Brink et al. 2012). Finally, there is no new commitment to removing economic incentives undermining the sustainable use of natural capital, including eliminating environmentally harmful subsidies, beyond the explicit reiteration of existing calls for reforming fossil fuel and fisheries subsidies.

In terms of institutional framework and intergovernmental arrangements for sustainable development, countries acknowledged the vital importance of an inclusive and transparent multilateral system for better addressing challenges for sustainable development and emphasised the need for an improved and more effective institutional framework (e.g. the need to promote and strengthen the effectiveness and efficiency of the UN system). As concrete outcomes, an agreement was reached to establish a universal intergovernmental high-level political forum, building on and replacing the Commission on Sustainable Development. The aim of this high-level political forum is, among other things, to provide political leadership, guidance, and recommendations for sustainable development and follow up and review progress in the implementation of sustainable development commitments.

The Rio +20 participants also reaffirmed the need to strengthen international environmental governance within the context of sustainable development. To support this objective a decision was made to strengthen the role of UN Environment Programme (UNEP) as the leading global environmental authority responsible for setting the global environmental agenda. This included, for example, agreeing to strengthen UNEP's governance structure, responsiveness and accountability to Member States and to guarantee secure, stable, adequate and increased financial resources for the programme from the regular budget (including UN budget and voluntary contributions). While a disappointment to many of those who had hope for an "upgrade" of UNEP into a fully established UN institute (World Environmental Organisation), the political agreement to reinforce UNEP's institutional standing was nevertheless seen as a step to the right direction.

In addition to the above, a framework for thematic future action and follow-up was discussed and agreed in the meeting, building on the previous commitments. The identified key focal areas for action included, for example, poverty eradication, food security, water and sanitation, energy, sustainable tourism, transport, sustainable cities, health and population, jobs and employment, risk reduction, climate change and forests and biodiversity. In this context, a specific attention was given to oceans and seas where a number of commitments were reaffirmed or made, including a commitment to intensify global efforts to meet the 2015 target to maintain or restore fish stocks to levels that can produce maximum sustainable yield. 
The international commitments for conservation of biodiversity (e.g. the global Biodiversity Targets for 2020 adopted in Nagoya in 2010, so called Aichi Targets) were reiterated, emphasising both the intrinsic value of nature and its role in underpinning socio-economic development while highlighting the importance of biodiversity conservation, enhancing habitat connectivity and building ecosystem resilience. In addition, the conservation (or restoration) of biodiversity, ecosystem and related services was recognised as an integral part of action on food security and sustainable agriculture, water supply and sanitation, and sustainable development of mountain regions. Unfortunately, however, the Rio+20 outcome document falls short in highlighting important synergies between nature conservation and a number of other key areas, including the role of well-functioning ecosystems in supporting mitigation of and adaptation to climate change and reducing environmental risks. Also, there is no mention of nature's role in developing sustainable tourism and green jobs and maintaining mental health.

Finally, building on the above, an agreement was reached to complement the Millennium Development Goals (MDSs) adopted in 2000 with a set of dedicated goals for sustainable development (SDGs). While no concrete goals were established in Rio, a decision was made to establish an inclusive and transparent intergovernmental process for developing SDGs. Let by an intergovernmental committee, comprising thirty experts nominated by the five UN regional groups, the process of developing SDGs is foreseen to be concluded by 2014 .

\section{Conclusions: it is up to us to shape the future we want}

While the UN and government representatives have tried their best to portray the rather timid political commitments in the best light possible, the outcomes of Rio+ 20 have been greeted with a wave of unveiled disappointment by NGOs and other civil society groups (e.g. Greenpeace 2012, Oxfam 2012, WWF 2012). The agreed Rio+20 declaration have been heavily criticised for the lack of concrete (new) actions and timelines. In addition, several stakeholders have raised their concern over the (seemingly) increased focus on sustainable growth instead of sustainable development in the declaration text.

The meagre global political outcomes and other concerns have led to a common consensus that the future progress on sustainable development will largely depend on actions taken by individual countries, blocs (e.g. the EU), companies and others. For example, while the EU in broad terms welcomed the Rio +20 declaration it also acknowledged that a number of its ambitions, including more concrete commitments on green economy and establishing an UN organisation for environment, were not fully achieved (EU press 2012).

Fortunately, however, the broader developments in the context of Rio+20 indicate that, regardless of the meagre global political outcome, there is a wide ranging interest in taking concrete actions towards more sustainable future. For example, hardly any companies and businesses were present in the first UN conference in 1992 whereas 
twenty years later they were a prominent part of the conference crowd, e.g. responsible for organising several of the over 500 side events during the conference.

In addition, a significant number of new commitments were made to complement existing global endeavours for sustainable development. For example, over fifty countries and close to ninety private companies committed to the World Bank initiative on developing natural capital accounts to support green economy, e.g. exploring the integration of (key) ecosystem services into accounting frameworks (WAVES 2012). Furthermore, more than 50 billion USD was pledged by private investors to help to implement the UN chief Ban Ki-moon's “Sustainable Energy For All” initiative (Sustainable Energy Initiative 2012). All and all, Rio+20 process resulted in close to 700 voluntary commitments for sustainable development, mobilising more than 513 billion USD worth of funding from government, business and civil society groups. These voluntary commitments cover a range of areas including energy, transport, green economy, disaster reduction, desertification, water, forests and agriculture (UNCSD 2012a).

The true key to success of Rio+20 is whether the above commitments will also be realised and whether the "leading by example" encourages others to follow suit and also develop partnerships to help address the inter-linked environmental, social and economic challenges. For example, the (already started) transition to a green economy in the context of sustainable development and poverty alleviation has not stalled at Rio, but neither has it been catalysed and accelerated sufficiently. Similarly, while the global targets for biodiversity were reaffirmed in Rio a range of concrete activities remains to be taken to ensure that these targets are met by the 2020 deadline. Therefore, what is needed is more conviction, more commitments and more implementation.

\section{References}

EU press (2012) EU press statement on the outcomes of Rio+20. Online: http://europa.eu/ $\mathrm{rapid} /$ pressReleasesAction.do? reference $=\mathrm{MEMO} / 12 / 461$ \&language $=\mathrm{fr}$

Greenpeace (2012) Closing statement on Rio+20 by Greenpeace. Online: http://www.greenpeace.org/international/en/press/releases/Greenpeace-Press-Statement-Rio20-Earth-Summit-a-failure-of-epic-proportions/

Oxfam (2012) Closing statement on Rio+20 by Oxfam. Online: http://www.oxfam.org.uk/ media-centre/press-releases/2012/06/rio-oxfam-final-statement

Sustainable Energy Initiative (2012) "Sustainable Energy for All” initiative. Online: http:// www.sustainableenergyforall.org/

ten Brink P, Mazza L, Badura T, Kettunen M, Withana S (2012) Nature and its Role in the Transition to a Green Economy. Executive Summary. Online: http://www.teebweb.org/ Portals/25/Documents/TEEBnature-green\%20economy\%20final.pdf

UNCSD (2012a) Rio+20 Conference. Online: http://www.uncsd2012.org/index.html

UNCSD (2012b) Rio+20 declaration - "The Future We Want" (UN document A/66/L.56). Online: http://daccess-dds-ny.un.org/doc/UNDOC/GEN/N12/436/88/PDF/N1243688. pdf?OpenElement 
UNEP (2011) Towards a Green Economy: Pathways to Sustainable Development and Poverty Eradication - A Synthesis for Policy Makers. Online: www.unep.org/greeneconomy

WAVES (2012) World Bank's WAVES initiative on natural capital accounting. Online: http:// www.wavespartnership.org/waves/

WWF (2012) Closing statement on Rio+20 by WWF. Online: http://wwf.panda.org/wwf_ news/?205343 